\title{
PATOLOGI BIROKRASI DALAM PELAYANAN PUBLIK DI KANTOR DINAS KEPENDUDUKAN DAN PENCATATAN SIPIL KABUPATEN BIAK NUMFOR
}

\author{
Rudiyansyah \\ Program Studi Administrasi Publik, Fakultas Ilmu Administrasi \\ Institut Ilmu Sosial dan Ilmu Politik YAPIS Biak \\ Email : rudyansyah488@gmail.com
}

\begin{abstract}
Abstrak
Tujuan dari penelitian ini, untuk mengetahui Patologi Birokrasi di Dinas Kependudukan dan Catatan Sipil Kabupaten Biak Numfor, Penelitian ini mengunakan metode deskriptif kualitatif yang menggambarkan pada realitas perilaku/penyakit pegawai negri sipil dalam pelayanan public yang disebut (Patologi Birokrasi). Obyek penelitian di Dinas Kependudukan dan Catatan Sipil Kab. Biak Numfor, dengan waktu 3 bulan, teknik pengumpulan data dilakukan dengan menggunakan teknik observasi, wawancara dan dokumentasi. Pelayanan public yang dilakukan oleh aparatur pemerintah, bertujuan untuk memberikan pelayanan terhadap masyarakat untuk meningkatkan segala aktifitas dilakukan untuk mencapai tujuan. Dari hasil penelitian, bahwa patologi birokrasi dalam pelayanan publik Di Kantor Dinas Kependudukan dan Pencatatan Sipil Kabupaten Biak numfor masih sering terjadi. Yang dapat dilihat dari 3 indikator yang penulis gunakan untuk membuktikan berbagai patologi yang muncul dalam pelayanan publik yang pertama yaitu pengaburan masalah, diskriminasi, dan cara kerja berbelit-belit. Adapun upaya-upaya yang dapat dilakukan untuk meminimalisir berbagai patologi birokrasi Di Kantor Dinas Kependudukan dan Pencatatan Sipil Kabupaten Biak numfor berdasarkan hasil penelitian dan wawanara penulis dengan informan, yaitu pertama, regulasi (hukum) yang tepat dan tegas. Kedua, menciptakan kondisi sosial dan spiritual yang baik. Ketiga, penjelasan-penjelasan yang logis, dan keempat penyederhanaan kerja (flat organization).
\end{abstract}

Kata Kunci: Patologi Birokrasi, Pelayanan Public.

\section{PENDAHULUAN}

Patologi birokrasi (Bureau pathology) adalah himpunan dari perilakuperilaku birokrat yang disfungsional. Red tape merupakan awal kemunculan dari sebuah patologi dalampelayanan publik. Red tape disebabkan adanya kecenderungan alami yang terjadi didalam tubuh dan para birokrat yang tercetak dari rutinitas kegiatan mereka sendiri. Birokrasi yang semestinya dapat lebih efesien dalam proses pelayanan public justru semakin berbelit-belit karena para birokrat dalam melakukan tugasnya sebagai pelayan publik terkesan setengah hati. Dari sifat inilah kemudian lahir berbagai patologi birokrasi seperti nepotisme, penyalahgunaan wewenang, korupsi dan berbagai penyakit birokrasi yang menyebabkan aparat birokrasi di negara berkembang pada umumnya memiliki kredibilitas yang rendah.

Kecenderungan birokrasi dalam pelayanan pada masyarakat modern benarbenar dipandang memprihatinkan, sehingga digambarkan adanya ramalan mengenai makin menggejalanya dan berkembangnya praktek-praktek birokrasi yang paling rasionalpun tidak bisa lagi dianggap sebagai 
kabar menggembirakan, melainkan justru merupakan pertanda malapetaka dan bencana baru yang menakutkan (Blau dan Meyer, 2000: 3). Menurut Islamy (1998: 8), birokrasi dikebanyakan negara berkembang termasuk Indonesia cenderung bersifat patrimonialistik : tidak efesien, tidak efektif (over consuming and under producing), tidak obyektif, menjadi pemarah ketika berhadapan dengan kontrol dan kritik, tidak mengabdi kepada kepentingan umum, tidak lagi menjadi alat rakyat tetapi telah menjadi instrumen penguasa dan sering tampil sebagai penguasa yang sangat otoritatif dan represif. Meskipun sudah menjadi gejala yang sangat umum, ternyata pada setiap konteks sistem budaya masyarakat, secara empirik birokrasi dan birokratisasi terlihat dalam pola perilaku yang beragam.

Dinas Kependudukan dan

Pencatatan Sipil merupakan salah satu instrumen daerah yang sangat vital fungsinya yang tugas pokoknya melaksanakan urusan pemerintahan daerah berdasarkan azas otonomi dan tugas pembantuan di bidang kependudukan dan pencatatansipil. Sebagai salah satu intrumen birokrasi yang banyak bersentuhan/ berhubungan langsung dengan masyarakat, harusnya mampu memberikan pelayanan yang berdaya guna serta pelayanan yang efektif dan efesien.

Serangkaian contoh penyakit (patologi) birokrasi yang lazim dijumpai dan dikeluhkan masyarakat dalam hal pelayanan publik di Kantor Dinas Kependudukan dan Pencatatan Sipil Kabupaten biak Numfor yang relatif sama dengan pendapat yang dikemukakan Siagian ( 1994: 40-117 ) mengenai patologi birokrasi khususnya pelayanan publik yaitu pengaburan masalah, tidak adil, menerima sogok, tidak sopan, sikap tidak acuh dan cara kerja yang berbelit-belit.

Dalam konteks perkembangan ilmu pengetahuan, pemahaman tentang pengetahuan birokrasi mulai dikenal seiring dengan perkembangan konsep negara modern. Menurut Taliziduhu Ndraha, istilah birokrasi berasal dari dua akar kata, yaitu bureau (burra, kainkasar penutu pmeja), dan crazy, ruler. Keduanya membentuk kata breau-crazy. Selanjutnya, pemerintahan birokratik adalah pemerintahan tanpa partisipasi pihak yang diperintah (M. Crozier dalam Riggs, 1971; 76).

Konsep sibirokrasi dalam ilmu sosial merupakan usaha-usaha modern untuk mendorong kearah proliferasi konsep lebih lanjut. Untuk menjaga perspektif perkembangan konsep birokrasit ersebut, penulisan tentang birokrasi modern akan ditelaah berdasarkan konsep yang telah biasa digunakan, mengacu pada berbagai afiliasi bidang ilmu, kecenderungan teoritik dan strategi-strategi konsep tual atau elaborasi dari pengertian-pengertian birokrasi yang telah baku.

\section{Birokrasi Sebagai Organisasi Rasional}

Gagasan birokrasi yang memandang birokrasi sebagai suatu mekanisme sosial yang memaksimumkan efisiensi dan juga sebagai suatu bentuk organisasi sosial yang memiliki ciri-ciri khas merupakan hubungan antara atribut-atribut suatu lembaga sosial dan akibat-akibatnya, kemudian diarahkan pada pendefinisian birokrasi sebagai organisasi yang memaksimumkan efisiensi dalam administrasi yang selanjutnyadigunakan secara netral untuk mengacu kepada aspek-aspek administrasif dari organisasi-organisasi sebagaimana dikemukakan oleh Peter Blau (Albrow, 1989 : 83). 


\section{Birokrasi Sebagai Inefisiensi Organisasional}

Konsep birokrasi sebagai organisasi rasional merupakan kajian yang senantiasa ditelaah oleh para akademisi. Tetapi untuk mengembangkan konsep birokrasi sebagai organisasi yang tidak efisien tidak membutuhkan banyak tradisi akademis. Victor Thompson mengatakan bahwa birokrasi tidak mengenal belas kasihan tidak pula mengenal cinta kasih dikatakan selanjutnya bahwa birokrasi itu bersifat "impersonalitas" (Miftah Thoha, 2002 : 102),

M. De Gournay memandang bahwa birokrasi merupakan sesuatu yang biasanya dikeluhkan, para pejabat, para juru tulis, para sekretaris, para inspektur dan para intendan (manajer) yang diangkat bukannya untuk menguntungkan kepentingan umum (Albrow, 1989 : 1).

Munculnya patologi birokrasi (Bureaupathology) dikenal sejak hadirnya rutinitas kegiatan yang menyibukkan para birokrat itu sendiri dan menciptakan aktifitas yang berbelit-belit. Kemudian kondisi ini dikenal dengan istilah Red Tape (pita merah) yakni birokrasi yang berbelit-belit sehingga menciptakan perilaku birokrasi yang sangat bertentangan dengan tujuan mulia kehadiran birokrasi itu sendiri di tengah-tengah masyarakat. Kajian dan eksprimen terhadap patologi birokrasipun kian berkembang dan menghasilkan banyak pandangan atau teori tentang patologi birokrasi. Pada kenyataannya negara berkembang telah menjadi 'ruang dan tempat' tumbuh suburnya patologi birokrasi.

Seperti Indonesia sebagai negara berkembang masih dalam selimut patologi birokrasi, mulai dari birokrasi pusat hingga birokrasi di daerah. Bahwa ternyata desentralisasi atau otonomi daerah yang sedang dan terus dijalani bangsa ini belum mampu menyingkirkan patologi birokrasi, bahkan dibeberapa daerah kita menyaksikan semakin mengukuhkan patologi birokrasi itu sendiri, citra buruk tersebut semakin diperparah dengan isu yang sering muncul kepermukaan, yang berhubungan dengan kedudukan dan kewenangan pejabat publik, yakni korupsi dengan beraneka ragam bentuknya, serta lambatnya pelayanan, dan diikuti dengan prosedur yang berbelit-belit atau yang lebih dikenal dengan efek pita merah (red-tape).

Kondisi yang mengakibatkan tumbuh dan berkembangnya patologi birokrasi adalah akibat pembiaran terhadap lahir dan tumbuhnya benih-benih gejala patologi birokrasi itu sendiri. Seperti kita ketahui, arti patologi dalam ilmu kedokteran adalah ilmu tentang penyakit. Berbagai penyakit yang mungkin sudah "di deritanya" atau mengancam akan "menyerangnya" perlu didefinisikan untuk kemudian di carikan terapi pengobatan yang paling efektif. Harus diakui bahwa tidak ada birokrasi yang sama sekali bebas dari berbagai patologi birokrasi, sebaliknya tidak ada birokrasi yang menderita semua "penyakit" birokrasi.

Analogi itulah yang diterapkan oleh Siagian ( 1989: 310 ) yang diberlakukan bagi suatu birokrasi. Artinya, agar seluruh birokrasi pemerintahan negara mampu menghadapi berbagai tantangan yang mungkin timbul, baik yang sifatnya politis, ekonomi, sosial-kultural dan teknologikal, berbagai "penyakit" yang mungkin sudah dideritanya atau mengancam akan menyerangnya perlu diidentifikasikan untuk kemudian dicarikan terapi pengobatannya yang paling efektif. Harus diakui bahwa tidak ada birokrasi yang sama sekali bebas dari berbagai patologi birokrasi. Sebaliknya 
tidak ada birokrasi yang menderita semua "penyakit" birokrasi.

\section{Jenis-jenis Patologi Birokrasi}

Menurut Siagian (1994: 310-1410), Patologi birokrasi dapat dikategorikan pada lima kelompok, yaitu :

$>$ Patologi yang timbul karena persepsi dan gaya manajerial para birokrat. Diantara patologi jenis ini antara lain, penyalahgunaan wewenang dan jabatan, menerima suap, arogansi dan intimidasi, kredibilitas rendah, dan nepotisme.

$>$ Patologi yang disebabkan karena kurangnya pengetahuan dan keterampilan para petugas pelaksana birokrasi. Diantara patologi jenis ini antara lain, ketidak telitian dan ketidakcekatan, ketidak mampuan menjabarkan kebijakan pimpinan, rasa puasdiri, bertindak tanpa pikir, kemampuan rendah, tidak produktif, dan kebingungan.

$>$ Patologi yang timbul karena tindakan para birokrat yang melanggar norma hukum dan peraturan perundangundangan. Diantara patologi jenis ini antara lain, menerima suap, korupsi, ketidakjujuran, kleptokrasi, dan mark upanggaran.

> Patologi yang dimanifestasikan dalam perilaku para birokrat yang bersifat disfungsional. Diantara patologi jenis ini antara lain, bertindak sewenang-wenang, konspirasi, diskriminatif, dan tidakdisiplin.

> Patologi yang merupakan akibat situasi dalam berbagai analisis dalam lingkungan pemerintahan. Diantara patologi jenis ini antara lain, eksploitasi bawahan, motivasi tidak tepat, beban kerja berlebihan, dan kondisi kerja kurang kondusif.
Serangkaian contoh penyakit (patologi) birokrasi yang lazim dijumpai dan dikeluhkan masyarakat dalam pelayanan publik sejalan dengan identifikasi yang dilakukan oleh Siagian (1994: 40-117), yaitu:

\section{Pengaburan masalah}

Merupakan kenyataan bahwa dalam kehidupan setiap organisasi pasti akan timbul berbagai permasalahan. Faktor-faktor penyebabnya berbeda-beda ada yang bersifat politis, ekonomi, hukum, budaya, administratif, ataupun teknikal. Dengan adanya pengaburan masalah ini akan membuat interpretasi sedemikian rupa, sehingga permasalahan yang sebenarnya sederhana, dibuat menjadi sangat rumit. Akibatnya, tindakan penyelesaian menjadi berbelit-belit dan menyita tenaga, waktu, pikiran dan perasaan ( inefesiensi) dalam hal pelayanan.

\section{Diskriminasi}

Sebagai penyakit birokrasi, tindakan diskriminatif dapat menghinggapi bukan hanya para pejabat pimpinan, akan tetapi juga para pelaksana kegiatan operasional. Hal ini dapat dilihat dari pengurusan KTP, akte kelahiran maupun KK di kantor Dinas Kependudukan dan Pencatatan sipil dengan adanya perlakuan diskriminatif dalam pelayanannya. Bagi mereka yang memiliki keluarga atau orang dekat yang bekerja di instansi tersebut akan diutamakan pelayanannya berbeda dengan mereka yang tidak memiliki keluarga atau orang dekat di instansi itu. Begitu pula jika yang datang mengurus adalah orang yang penting (pemimpin) maka akan diutamakan pelayanannya berbeda dengan masyarakat biasa, yang biasanya akan lamban pengurusannya. 


\section{Tidak Sopan}

Hal yang selalu ditekankan dalam pembahasan tentang patologi birokrasi adalah bahwa dalam menjalankan tugasnya sebagai pelayan masyarakat dan abdi negara, para anggota birokrasi hendaknya jangan berorientasi pada kekuasaan melainkan pada pengabdian dan pelayanan. Orientasi kekuassaan bertolak belakang dengan peranannnya selaku abdi negara dan abdi masyarakat. Padahal dalam suatu masyarakat yang beradab, sikap sopan merupakan bagian tata krama sosial.

\section{Cara kerja yang berbelit-belit}

Dengan alasan faktual atau tidak, birokrasi pemerintah sering dilempari tuduhan yang seolah-olah salah satu ciri birokrasi adalah membuat suatu pekerjaan yang sesungguhnya sederhana menjadi rumit. Dengan kata lain cara kerja yang berbelit-belit. Buktinya, demikian tuduhan tersebut sesuatu pekerjaan yang semestinya dapat terselesaikan dalam waktu singkat, baru dapat tuntas setelah makan waktu yang relatif lama. Sering ditambahkan pula bahwa berbelit-belit berarti suatu pekerjaan yang sesungguhnya dapat diselesaikan oleh seseorang dalam kenyataannya melibatkan beberapa meja yang tentunya berakibat kepada "mata rantai penyelesaian yang panjang".

Inilah serangkaian patologi birokrasi dalam pelayanan publik yang terjadi dihampir seluruh intansi yang bersentuhan/ berhubugan langsung dengan masyarakat disetiap daerah tanpa terkecuali Di Kantor Dinas Kependudukan dan Pencatatan Sipil Kabupaten Biak Numfor. Meskipun sesungguhnya langkah-langkah perbaikan mutu dan pelayanan terus diupayakan pemerintah agar dapat memberikan keamanan, kenyamanan, kelancaran dan kepastian hukum yang dapat dipertanggung jawabkan.

\section{Pengertian Pelayanan Publik}

Di Indonesia penggunaan istilah pelayanan publik dianggap memiliki kesamaan arti dengan istilah pelayanan umum atau pelayanan masyarakat (Yogi dan Ikhsan, 2006: 222). Sebab ketiga istilah tersebut dipergunakan secara "interchangeable" dan dianggap tidak memilki perbedaan mendasar. Dalam Kamus Besar Bahasa Indonesia dinyatakan pengertian pelayanan bahwa pelayanana dalah suatu usaha untuk membantu menyiapkan (mengurus) apa yang diperlukan orang lain. Pelayanan berfungsi sebagai sebuah sistem yang menyediakan apa yang dibutuhkan oleh masyarakat. Sementara istilah publik yang berasal dari bahasa Inggris terdapat beberapa pengertian yang memiliki variasi arti dalam bahasa Indonesia yaitu umum, masyarakat, dan negara. Publik dalam pengertian umum atau masyarakat dapat kita temukan dalam istilah public offering (penawaranumum), public ownership (milikumum), dan public utility (perusahaanumum) dan lain-lain.

Rendahnya produktifitas kerja dan mutu pelayanan yang diberikan oleh para aparat birokrasi pemerintahan kepada masyarakat merupakan wujud dari patologi birokrasi, yang mana salah satu penyebabnya adalah tindakan dan perilaku aparat yang disfungsional atau negatif. Masalah perilaku aparat akan menjadi semakin rumit, apabila dalam birokrasi tidak terdapat suatu usaha yang bertujuan untuk menyadarkan para aparat birokrasi agar tidak lagi melakukan hal-hal yang disfungsional yang akan membuat kinerja kerja, produktifitas kerja dan mutu pelayanan akan menjadi rendah karena 
para pegawai yang sering melakukan penyimpangan dalam hal pelayanan.

Berangkat dari konsep tersebut, maka skema penulisan dapat digambarkan dalam bagan sebagai berikut :

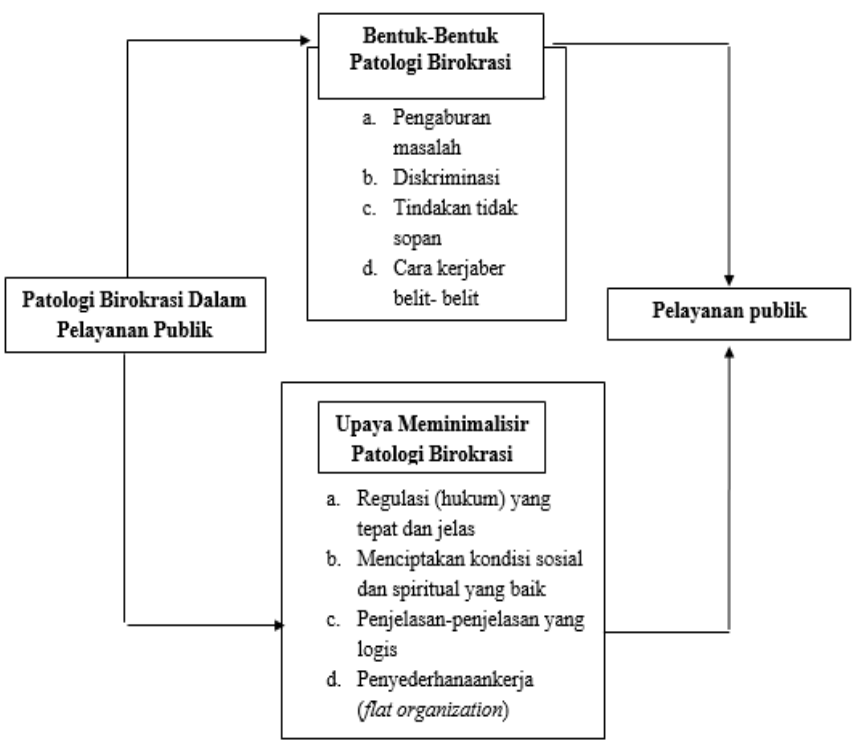

\section{METODE PENELITIAN}

Penelitian ini bersifat kualitatif dimana dengan tipe penelitian studi kasus, penelitian berfokus pada patologi birokrasi dan pelayanan publik di dinas kependudukan dan catatan sipil. Data penelitian diperoleh melalui sumber primer yaitu penelitian dilapangan dengan melalui wawancara SKPD dan masyarakat terkait patologi birokasi dalam pelayanan publik, selain itu intervew dari beberapa informan dan data sekunder diperoleh dari dokumen.

\section{HASIL DAN PEMBAHASAN}

\section{Bentuk-Bentuk Patologi Birokrasi Dalam Pelayanan Publik}

Berbagai bentuk patologi birokrasi yang sering kita temui dan dikeluhkan masyarakat dalam pelayanan publik sejalan dengan pemikiran Siagian ( 1994 : 310 -1410 ) yang mengkategorikan patologi birokrasi timbul dari lima hal yaitu pertama patologi yang timbul karena persepsi dan gaya manajerial para birokrat, kedua patologi yang disebabkan karena kurangnya pengetahuan dan keterampilan para petugas pelaksana birokrasi, ketiga patologi yang timbul karena tindakan para birokrat yang melanggar norma hukum dan peraturan perundang-undangan, keempat patologi yang dimanifestasikan dalam perilaku para birokrat yang bersifat disfungsional, dan yang kelima adalah patologi yang merupakan akibat situasi dalam berbagai analisis dalam lingkungan pemerintahan.

1. Pengaburan masalah

Merupakan kenyataan dalam kehidupan setiap organisasi yang membuat interpretasi sedemikian rupa, sehingga permasalahan yang sebenarnya sederhana dibuat menjadi sangat rumit. Kadangkadang terjadi bahwa para pejabat pimpinan mengaburkan bentuk dan sifat permasalahan, karena dengan adanya pengaburan itu, penyelesaiannya dapat direkayasa sedemikian rupa sehingga menguntungkan pejabat yang bersangkutan dalam arti kedudukannya. Akibatnya, tindakan penyelesaian menjadi berbelit-belit dan menyita tenaga, waktu, pikiran dan perasaan ( inefesiensi ) dalam hal pelayanan. Untuk mengetahui ada tidaknya patologi birokrasi seperti yang telah dibahas di atas dalam hal pelayanan publik di Kantor Dinas Kependudukan dan Pencatatan Sipil Kab. Biak Numfor, maka dapat diketahui menggunakan indikator, yaitu :

$>$ Memperumit pelayanan

Merupakan suatu tindakan dengan membuat palayanan yang sebenarnya mudah dan sederhana menjadi rumit dan berbelit-belit yang berimplikasi terhadap pelayanan yang tidak efesien. Masalah ini sering ditemukan aparatur pemerintah dalam 
proses pelayanan, khususnya secara administrasi, sehingga yang terjadi kebosanan masyarakat dan rasa enggan untuk mengurus Ktp, Kk, Akte lahir dll, seperti yang di ungkap H.Y. Dalam pelayanan,

Bahwa proses pelayanan disbudcapil sangat membosankan, akibatnya pelayanan yang rumit, antrian yang lama dan ruangan yang tak mendukung dalam pengurusan (Wawancara 16/10/2019).

\section{Diskriminasi}

Salah satu prinsip kepemimpinan yang telah diakui kebenarannya adalah sikap objektif dan rasional dalam memperlakukan para bawahan yang didasarkan pada kriteria yang jelas. Prinsip ini berlaku dalam seluruh proses manajemen sumber daya manusia, termasuk salam pemberian penghargaan dan pengenaan sanksi administratif. Tidak ada tempat untuk bertindak atas dasar pilih kasih, karena pertimbangan-pertimbangan yang tidak rasional seperti nepotisme, dan primordialisme.

Sesungguhnya, prinsip yang sama berlaku pula dalam pemberian pelayanan kepada para masyarakat. Semua masyarakat harus mendapatkan perlakuan yang sama tanpa adanya diskriminasi, sepanjang masyarakat tersebut sama-sama memenuhi persyaratan yang telah ditentukan untuk menerima pelayanan yang diinginkannya. Pertimbangan-pertimbangan yang irasional, sepertinepotisme dan primordialisme yang tidak seharusnya digunakan dalam setiap pemberian pelayanan kemasyarakat. Untuk mengetahui ada tidaknya tindakan diskriminasi sebagai patologi birokrasi dalam hal pelayanan publik di Kantor Dinas Kependudukan dan Pencatatan Sipil Kab.
Biak, maka dapat diketahui dengan menggunakan dua indikator yaitu :

$>$ Sikap pilih kasih

Tindakan diskriminatif dalam memberikan pelayanan dengan cara memberikan pelayanan yang tidak adil terhadap masyarakat dengan mengutamakan yang memiliki keluarga di instansi atau mereka yang memangku jabatan. Seperti yang di ungkap B.W, dalam pelayana;

Bahwa

didalam

pengurusan Ktp maupun Kk biasanya lama jika tidak memiliki kerabat di dalamnya, sehingga kepengurusan biasa selesai dalam waktu 3 hari kini menjadi 7-10 hari.(Wawancara 17/10/2019).

\section{$>$ Sikap tidak adil}

Perlakuan diskriminatif dalam pemberian pelayanan yang berbeda antara orang yang satu dengan orang yang lainnya, atas dasar pertimbanganpertimbangan tidak rasional ( nepotisme dan primordialisme ).

Hal ini sering ditemukan sikap diskriminatif yang dilakukan sebagaian pegawai yang bertugas dalam memberikan layanan terhadap masyarakat, seperti adanya keluarga atau kerabat yang ada di dalam kantor.

3. Tindakan Tidak Sopan

Aparat birokrasi dalam menjalankan tugasnya sebagai pelayan masyarakat dan abdi negara, hendaknya jangan berorientasi pada kekuasaan melainkan pada pengabdian dan pelayanan. Orientasi kekuasaan bertolak belakang dengan peranannya selaku abdi negara dan abdi masyarakat. Padahal dalam suatu masyarakat yang beradab, sikap sopan merupakan bagian tata krama sosial. Untuk mengetahui sikap yang ditunjukkan oleh 
aparatur birokrasi di Kantor Dinas Kependudukan dan Pencatatan Sipil maka penulis mengambil dua indikator, yaitu:

$>$ Sikap tidak peduli ( acuh )

Sikap tidak acuh merupakan salah satu akibat oriantasi kekuasaan yang dianut anggota birokrasi. Orientasi demikian menjelma dalam bentuk menonjolkan pandangan bahwa dialah yang dibutuhkan oleh masyarakat, yang berimplikasi terhadap sikap tidak acuh yang dimunculkan oleh birokrat terhadap masyarakat.

Anggota birokrasi seringkali ditemukan di beberpa kantor baik tingkat kelurahan, kecamatan, maupun di dinas kependudukan dan catatan sipil memiliki sifat acuh dalam pelayanan terhadap masyrakat sehingga menimbulkan kerugian terhada publik. Dimana pada sikap acuh itu seperti, tidak menyapa, cuek, sombong, dan bertingkah laku yang tak baik. Seperti yang diungkapkan D.Y, pelayanan sikap tak acuh;

Bahwa di dinas

kependudukan dan catatan sipil masih ada beberapa orang (kecil) birokrat yang bertingkah laku seperti itu (acuh), sehingga menimbulka ketidak nyamanan (Wawancara 17/10/2019).

Sikap tidak ramah

Merupakan sikap yang ditonjolkan oleh aparat dalam memberikan pelayanan, hal ini akibat dari orientasi anggota birokrasi pada kekuasaan, ada kalanya bertindak dengan cara tidak atau kurang ramah seperti penggunaan katakata yang menyinggung perasaan orang lain dalam hal ini masyarakat.

Sikap yang di tampakkan oleh anggota birokrasi dapat melanggar nilainilai pelayanan publik, seolah merasa bahwa masyarakatlah yang butuh dengan kehadiran para birokrasi di pemerintahan. Seperti diungkapkan R.D, pelayanan yang tidak ramah;

Bahwa sebagai sikap pegawai dinas kependudukan dan catatan sipil bertingkah laku yang tidak semestinya, seperti diam, dan cuek sehingga masyarakat merasa tidak penting di hadapan mereka (Wawancara 17/10/2019).

4. Cara kerja yang berbelit-belit

Birokrasi pemerintah sering dilempari tuduhan yang seolah-olah salah satu ciri birokrasi adalah membuat suatu pekerjaan yang sesungguhnya sederhana menjadi rumit. Pekerjaan yang semestinya dapat terselesaikan dalam waktu singkat, baru dapat tuntas setelah makan waktu yang relatif lama. Hal inilah yang kemudian memunculkan wacana mengenai kinerja birokrasi yang lamban dalam menyelesaikan tugas-tugasnya dalam hal ini adalah pelayanan terhadap masyarakat. Untuk mengetahui patologi atau permasalahan birokrasi terhadap kelambanan atau inefesiensi yang timbul di Kantor dinas Kependudukan dan Pencatatan Sipil maka penulis mengambil dua indikator, yaitu :

$>$ Prosedur yang panjang

Merupakan mekanisme pengurusan yang memiliki prosedur yang panjang. Hal inilah berimplikasi terhadap kinerja aparat yang berbelit-belit ( tidak efesien ).

Seperti yang terjadi di dinas kependudukan dan catatan sipil dalam pengurusan Ktp atau Kk harus melengkapi prosedur yang panjang, seperti pengantar dari kelurahan/kampung, Kecamatan/distrik. Hal seperti tentunya dapat memakan 
waktu yang panjang, apalagi masyarakat yang memiliki tempat tinggal yang jauh tentu dapat melakukan pengurusan dalam waktu berminggu-minggu.

$>$ Dokumen - dokumen yang banyak

Merupakan pengunaan dokumendokumen yang banyak dalam melakukan setiap pengurusan yang berarti menyita waktu, tenaga dan pikiran masyarakat lebih banyak.

Salah satu yang penting dalam pengurusan KK atau KTP dengan melengkapi dokumen yang rumit seperti adanya surat pengantar dari kelurahan, distrik baru bisa sampai ke dinas kependudukan dan catatan sipil, sebagaimana diungkapkan oleh B.P. Selaku masyarakat yang mengurus akte kelahiran

Dalam kepengurusan Akte kelahiran sangatlah rumit sehingga rela berbolak balik antara kantor satu dengan yang lainnya, dimulai dari kantor dinas kependudukan dan catatan sipil turun ke kelurahan dan kecamatan dalam melengkapi dokumen dan kembali ke dinas (Wawancara 17/10/2019).

\section{Upaya-Upaya Meminimalisir Patologi Birokrasi}

Seperti yang telahdi ketahui, arti patologi dalam ilmu kedokteran adalah ilmu tentang penyakit. Pentingnya patologi ialah agar diketahui berbagai jenis penyakit yang mungkin diderita oleh manusia, meskipun sekaligus dimaklumi bahwa tidak ada manusia yang menderita semua jenis penyakit. Paling sedikit tidak pada waktu yang bersamaan.

Analogi itulah yang berlaku pula bagi suatu birokrasi. Artinya, agar seluruh birokrasi pemerintah negara mampu menghadapi berbagai tantangan yang mungkin timbul, baik yang sifatnya politis, ekonomi, sosio kultural dan teknologikal, berbagai "penyakit" yang mungkin sudah dideritanya atau mengancam akan menyerangnya perlu diidentifikasi untuk kemudian dicarikan terapi pengobatannya yang paling efektif. Harus diakui bahwa tidak ada birokrasi yang sekali bebas dari bebagai patologi birokrasi. Sebaliknya tidak ada birokrasi yang menderita semua "penyakit" birokrasi sekaligus. Adapun upaya-upaya yang dapat dilakukan untuk meminimalisir berbagai patologi birokrasi yang terjadi Di Kantor Dinas Kependudukan dan Pencatatan Sipil Kab. Biak Numfor, yaitu :

1. Regulasi (hukum) yang tepat dan tegas

Penerapan aturan-aturan yang jelas dan tegas dapat menindak lanjuti aparatur yang melakukan pelanggaran didalam proses pelayanan publik, sehingga masyarakat hal ini yang mendapat pelayanan dapat melaukan aktifitas dengan baik.

2. Penciptaan kondisi sosial dan spiritual yang baik

Untuk meminimalisir berbagai patologi birokrasi yang sering muncul dalam hal pelayanan maka penciptaan kondisi sosial dan spiritual yang baik merupakan salah satu cara yang efektif untuk membuat kesan sopan dan tidak kaku. Hal ini diharapkan mampu membuat suatu hubunngan yang baik antara aparat dengan masyarakat. Sebagaimana diungkapkan oleh M.S selaku kepala Dinas Kependudukan dan catatan sipil dengan mengatakan bahwa :

"Dengan membangun kerja sama supaya tetap ada hubungan yang 
tercipta baik dengan aparat maupun dengan masyarakat, kondisi seperti inilah yang sangat kami harapkan dapat terjadi mengingat instansi kami merupakan salah satu instansi yang paling banyak bersentuhan langsung dengan masyarakat banyak" (Wawancara 18/010/2019)

Hal yang sama pula diungkapkan oleh B.S selaku kepala bagian pencatatan sipil, dengan mengatakan bahwa:

"penciptaan hubungan yang harmonis dengan jajaran maupun dengan masyarakat dengan baik sehingga tidak ada jarak komunikasi antara aparat dengan masyarakat, hal tersebut dilakukan semata-mata untuk mempererat hubungan tali silaturahmi kami baik di dalam kantor maupun di luar kantor, baik antara aparat maupun dengan masyarakat",

(Wawancara 18/010/2019)

$$
\text { Berdasarkan dari kedua }
$$
informan di atas dapat dikatakan bahwa untuk menghilangkan kesan yang tidak sopan dan kaku pada Dinas Kependudukan dan Pencatatan Sipil salah satuupaya yang dapat dilakukana dalah menciptakan kondisi sosial dan spiritual yang baik dengan cara membangun kerjasama yang baik dan harmonisasi hubungan, baik antara aparat maupun dengan masyarakat.

3. Penjelasan-penjelasan yang logis

Pemberian penjelasan-penjelasan yang logis kepada pihak yang memerlukan pelayanan, hal ini dimaksudkan agar aparat tidak terkesan cuek atau tidak peduli terhadap masyarakat yang memerlukan pelayanan. Upaya ini dapat dilakukan oleh pimpinan atau pegawai operasional untuk menyampaikan halhal mengenai halangan-halangan yang mungkin terjadi yang menyebabkan adanya keterlambatan penyelesaian dalam berbagai pengurusan karena berbagaihal yang urgen secara logis kemasyarakat. Hal ini lebih dapat diterima oleh masyarakat ketimbang harus menunggu berhari-hari tampa adanya kepastian dan kejelasan penyelesaian yang mereka urus di instansi tersebut. Hal tersebut sesuai dengan yang diungkapakan oleh $\mathbf{M}$.S selaku kepala Dinas kependudukan dan catatansipil yang mengatakanbahwa :

"Diusahakan petugas lebih dari satu, sehingga ada petugas cadangan atau petugas yang memahami tugas-tugas lainnya dengan maksud tidak ada peyelesaian yang tertunda atau terlambat. Akan tetapi jika terjadi keterlambatan penyelesaian maka kami berusaha memberikan penjelasan yang logis dan santun agar masyarakat dapat memahami dan menerimanya".(Wawancara $18 / 10 / 2019)$

Hal yang sama juga diungkapkan oleh B.S selaku kepala bidang pencatatan sipil dengan mengatakan bahwa :

"kalaum asalah pegawai, kami selalu mempunyai petugas cadangan jadi pelayanan tetap dilaksanakan, namun jika pegawai sibuk sehingga beberapa masyarakat mempertanyakan penyelesaian apa yang mereka 
urus, maka kami selaku aparat memberikan mereka penjelasanpenjelasan yang logis agar merekapaham dan menerimanya, tapi tak dapat dipungkiri bahwa beberapa masyarakat juga biasanya tidak menerima apa yang kami sampaikan”. (Wawancara 18/10/2019)

Berdasarkan dari kedua informan di atas dapat disimpulkan bahwa penjelasan-penjelasan yang logis lebih dapat diterima oleh masyarakat, meskipun tidak dapat dipungkiri bahwa masih ada beberapa masyarakat yang kurang menerima hal tersebut, dengan alasan bahwa mereka telah $\mathrm{m}$ engurus berminggu-minggu bahkan berbulan-bulan akan tetapi apa yang mereka urus belum selesai. Sehingga aparat harus bekerja lebih ekstra lagi dalam menyampaikan berbagai masalah pada masyarakat sehingga penjelesan-penjelasan mereka dapat diterima oleh masyarakat. Karena penjelesan-penjelasan yang logis merupakan salah satu alternative yang dapat digunakan untuk meminimalisir patologi birokrasi dalam hal pelayanan yang selama ini diderita oleh birokrasi yang terkesan acuh tak acuh terhadap masyarakat.

4. Penyederhanaan kerja (flat organization)

Cara kerja berbelit-belit yang selama ini ditunjukkan birokrasi dapat dihilangkan dengan cara penyederhanaan kerja yang merupakan upaya yang dapat dilakukan oleh istansi yang bersangkutan, sasarannya antara lain memangkas rantai penyelesaian yaitu bagian-bagian yang tidak efektif dalam instansi yang berimplikasi terhadap pengurangan prosedur kerja yang selama ini menimbulkan rantai penyelesaian yang panjang sehingga tidak memunculkan rantai penyelesaian yang panjang lagi.

Hal tersebut sesuai dengan yang diungkapkan oleh kepala bagian pencatatan sipil B.S yang mengatakan bahwa :

"Melihat berbagai persoalan birokrasi yang selama ini susah untuk dihilangkan dalam hal mekanisme pengurusan berbelitbelit di instansiini, yang menyita waktu masyarakat yang cukup lama memang perlu adanya suatu perbaikan dari segi administrasi dan pelayanannya, salah satunya adalah penyederhanaan rantai penyelesaian (penyederhanaan kerja) yang diharapkan mampu mengatasi persoalan penyelesaian setiap pengurusan di isntansi ini sehingga setiap penyelesaian penguru dapa tlebih cepat"

(Wawancara 18/10/2019)

Hal senada juga di ungkapkan oleh salah satu staf bagian pencatatan sipil T.S, yang mengatakan bahwa :

"perlu adanya penyederhanaan kerja tapi tetap dalam koridor yang relevan dengan aturan-aturan yang berlaku, dengan harapan dapat mengurangi rantai penyelesaian yang panjang (berbelitbelit)".(Wawancara 18/10/2019)

Penyederhanaan kerja memang menjadi salah satu upaya yang dapat dilakukan untuk meminimalisir bahkan menghilangkan patologi birokrasi. Dengan adanya 
peyederhanaan kerja berdasarkan yang diungkapkan oleh duainforman di atas, dapat meminimalisir berbagai patologi birokrasi yaitu kinerja yang berbelitbelit yang saat ini telah diderita oleh hampir setiap lembaga birokrasi dengan tetap berdasarkan pada aturanaturan yang berlaku.

\section{DAFTAR PUSTAKA}

Albrow, Martin. 1989, Birokrasi, Tiara Wacana, Yogyakarta.

Effendi, Onong Uchjana. 1989, Kamus Indonesia, CV. Mandar Maju. Jakarta.

Harry Sarundajang, Sinyo, 2012, Birokrasi dalam Otonomi Daerah "Upaya Mengatasi Kegagalan”, Kata Hasta Pustaka, Jakarta.

Istianto, Bambang, 2011, Domokratisasi Birokrasi, Mitra Wacana Media, Jakarta

Makmur, 2007, Patologi Serta Terapinya Dalam Ilmu Admiistrasi dan Organisasi, Refika Aditama, Bandung.

Moerdiono. 1994, Birokrasi dan Administrasi Pembangunan : Beberapa Pemikiran Pemecahan, Pustaka Sinar Harapan, Jakarta.

Ndraha, Talidziduhu. 2003, Kybernology 1 (Ilmu Pemerintahan Baru), PT. Asdi Mahasatya, Jakarta.

Santoso, Priyo Budi. 1999, Birokrasi Pemerintah Orde Baru : Perspektif Kultural dan Struktural, Rajawali Press, Jakarta.

Setiono, Budi. 2002, Jaring Birokrasi, Pt. Gugus Press, Bekasi.
Siagian, S.P, 1994, PatologiBirokrasi. Analisis, Identifikasi dan Terapinya, Ghalia Indonesia, Jakarta.

Sinambela, Lijan.P, 2010, Reformasi Pelayanan Publik "Teori, Kebijakan, dan Implementasi”, Bumi Aksara, Jakarta.

Tarukan, Alfrida, 2012, Kualitas Pelayanan Kartu Tanda Penduduk Penduduk Pada Dinas Kependudukan dan Pencacatan Sipil Kabupaten Maтuju, Disertasi, Pascasarjana STIA LAN, Makassar.

Thoha, Miftah, 2009, Birokrasi Pemerintah Indonesia di Era Reformasi, Kencana Prenada Media Group, Jakarta.

\section{Dokumen-Dokumen}

Undang-Undang Nomor 210 Tahun 2009 Tentang Pelayanan Publik 